\title{
PENDIDIKAN AKIDAH AKHLAK SEBAGAI SOLUSI PENCEGAHAN LGBT
}

\author{
Ramadhani \\ UIN Sunan Kalijaga Yogyakarta \\ E-mail: ramadhanitigan@gmail.com
}

\begin{abstract}
Indonesia nowadays is troubled by the existence of LGBT (lesbian, gay, bisexual, and transgender) communities who demand recognition, legalization, and rejection of discriminatory acts against them. On the other hand, Indonesia is a godly country where the majority of the population is Muslim. It means that the majority of Indonesian people view this behavior as being at odds with Indonesia's noble values both in traditional and religious (Islamic) values. At first glance, some people will consider that the LGBT problem is a moral problem on which character education is considered as a solution. However, LGBT is essentially a matter of religious faith in particular the crisis of aqidah. Hence, Aqidah Akhlak education could be said having failed in producing the generations who are sturdy, strong, and have a high commitment to their religion. LGBT issue can't be seen merely as a crisis of character, because talking about character is talking about relative culture. While the Qur'an has explicitly said that LGBT is an unlawful act. Therefore, if the root of the problem is aqidah, then one of the solution is through Aqidah Akhlak education. In this case, Aqidah Akhlak education must be contextual, meaningful and lively. Through habituation, training, and role models, students are directed to think critically and orient themselves to problem solving, linking with other disciplines, and evaluations that are emphasizing spiritual aspect and attitude.
\end{abstract}

Keywords: Aqidah Akhlak education, Islamic perspective, LGBT prevention, moral.

\begin{abstract}
Abstrak
Dewasa ini Indonesia diresahkan dengan adanya komunitas LGBT yang menuntut pengakuan, pelegalan, dan penolakan tindakan diskriminatif terhadap individu LGBT. Di sisi lain, Indonesia merupakan negara berketuhanan dimana mayoritas penduduknya adalah beragama Islam. Artinya, mayoritas masyarakat Indonesia memandang perilaku ini berseberangan dengan nilai-nilai luhur Indonesia baik secara adat maupun nilai-nilai agama (Islam). Secara sepintas, sebagian orang akan menganggap bahwa persoalan LGBT adalah persoalan moral atau karakter. Oleh karena itu, pendidikan karakter dianggap solusi dalam penanggulangannya. Namun, pada hakikatnya LGBT adalah persoalan akidah (krisis akidah). Pendidikan Akidah Akhlak selama ini berarti masih belum berhasil melahirkan generasi yang kokoh,
\end{abstract}


kuat, dan memiliki komitmen yang tinggi terhadap agamanya. LGBT tidak dapat dipandang sebagai krisis karakter saja, karena berbicara tentang karakter maka berbicara tentang budaya yang relatif. Sementara Al-Qur'an secara gamblang mengatakan bahwa LGBT merupakan perbuatan yang haram. Karena itu, jika akar masalahnya adalah akidah maka salah satu solusinya adalah melalui pendidikan Akidah Akhlak. Dalam hal ini, pendidikan Akidah Akhlak harus berisfat kontekstual, bermakna dan hidup, metodenya melalui pembiasaan, pelatihan, dan teladan, siswa diarahkan untuk berpikir kritis dan berorientasi pada penyelesaian masalah, mengaitkan dengan disiplin ilmu lainnya, dan evaluasi yang digunakan menekankan pada aspek spiritual dan sikap.

Kata Kunci: Pendidikan Akidah Akhlak, perspektif Islam, pencegahan LGBT, moral

\section{Pendahuluan}

LGBT merupakan singkatan dari lesbian, gay, biseksual, dan transgender. Kini Indonesia sedang dikejutkan dengan isu yang oleh sebagian orang menyebutnya dengan istilah isu moral, krisis moral, krisis karakter, perilaku seksual yang menyimpang, gangguan kejiwaan, keberagaman perilaku seksual, dan lain sebaginya.

LGBT merupakan kaum minoritas di Indonesia. Perilaku ini sebenarnya sudah bukan lagi hal yang baru di Indonesia, akan tetapi invididu LGBT tidak memiliki tempat yang baik di masyarakat. Artinya, masyarakat Indonesia memiliki persepsi yang tidak baik untuk pelaku LGBT, sehingga individu LGBT tak jarang merasa diperlakukan secara diskriminatif. Hal demikian terjadi karena perilaku tersebut dianggap tidak sejalan atau sesuai dengan nilai-nilai universal yang dianut oleh mayoritas masyarakat Indonesia baik dari segi budaya, adat, maupun agama. Diperkuat pula oleh nilai-nilai Indonesia yang sarat dengan nilai keislaman. Dimana Islam dengan jelas dan mutlak mengecam dan melarang perilaku tersebut.

Di berbagai negara bagian di Amerika Serikat sudah banyak melegalkan perkawinan sejenis, yaitu di Connecticut, Iowa, Massachussets, Orgeon, New Hampshire, Newyork, Vermont, Maryland, Hawai, Maine, dan Washington DC. Pelegalan ini juga terjadi di Belanda, Belgia, Spanyol, Kanada, Afrika Selatan, Norwegia, Swedia, Portugal, Meksiko, Islandia, Argentina, Uruguay, Selandia Baru, Perancis, Denmark, Inggris, Wales, Skotlandia, Brazil, Luxemburg, Finlandia, 
Irlandia, dan selanjutnya Vietnam. Sementara Malaysia, Brunei, dan juga Indonesia (yang ada di Asia) masih menentang/melarang perilaku tersebut. ${ }^{1}$

Pelarangan dan pandangan buruk yang berbau diskriminatif terhadap perilaku ini kemudian menjadikan individu-individu LGBT di Indonesia mencari perlindungan dan pembenaran serta membutuhkan pengakuan dengan mengatasnamakan HAM dan keadilan sosial. Oleh karena itu, pada Hari Hak Asasi Manusia 10 Desember 2012 merupakan upaya pembelajaran yang pertama kali setingkat Asia yang dilakukan bersama organisasi-organisasi akar rumput dan para pimpinan komunitas LGBT di Asia dengan didampingi UNDP dan USAID. Tema yang mereka usung adalah "Being LGBT in Asia: A Participatory Review and Analysis of the Legal and Sosial Environment for Lesbian, Gay, Bisexual and Transgender (LGBT) Persons and Civil Society", yang berarti "Hidup Sebagai LGBT di Asia: Tinjauan dan Analisa Partisipatif tentang Lingkungan Hukum dan Sosial bagi Orang dan Masyarakat Madani Lesbian, Gay, Biseksual dan Transgender (LGBT)”. Kegiatan ini fokus di delapan negara prioritas yaitu Cina, Filipina, Indonesia, Kamboja, Mongolia, Nepal, Thailand dan Vietnam. Upaya ini mempelajari berbagai pengalaman yang dijalani LGBT dari sudut pandang pengembangan dan hak asasi. ${ }^{2}$ Selain itu, berbagai kegiatan juga digelar seperti kegiatan demonstrasi di berbagai kota besar di Indonesia termasuk Yogyakarta, Jakarta, Medan, dan kota lainnya. Tindakan terang-terangan ini semakin meresahkan masyarakat karena dikhawatirkan perilaku seksual yang dianggap menyimpang dan terlarang ini semakin menyebar apalagi mendapat persetujuan dari pemerintah.

Upaya unjuk diri ini kemudian mendapat perhatian atau respon dari publik termasuk pemerintah. Hingga saat ini, sebagian besar pejabat atau pemerintah tidak setuju atas perilaku ini apalagi menyetujui pelegalan LGBT di Indonesia. Bahkan

${ }^{1}$ Masmuri dan Syamsul Kurniawan. "Penyimpangan Seksual: Sebuah Interpretasi Teologi, Psikologi dan Pendidikan Islam", dalam Jurnal Raheema: Jurnal Studi Gender dan Anak, Vol. 3 No. 1, 2016, 103.

${ }^{2}$ Dede Oetomo dan Khanis Suvianita, "Hidup sebagai LGBT di Asia: Laporan Nasional Indonesia (Tinjauan dan Analisa Partisipatif tentang Lingkungan Hukum dan Sosial bagi Orang dan Masyarakat Madani Lesbian, Gay, Biseksual, dan Transgender)", 2013, 8. 
kalangan agama pun ikut bersuara dengan penolakan para pemuka agama atas pelegalan atau pengakuan komunitas LGBT di Indonesia serta menuntut pemerintah untuk mengeluarkan undang-undang anti/kontra LGBT. Padahal komunitas LGBT sendiri jelas unjuk diri untuk mendapat dukungan, pengakuan, dan perlindungan dari pemerintah dengan dibuatkannya perundang-undangan yang berpihak pada mereka.

Perundang-undangan mengenai LGBT di Indonesia selama ini pada tingkat nasional memang belum dibuat. Namun, di beberapa daerah di Indonesia seperti Banda Aceh dan Palembang telah membuat peraturan mengenai larangan perzinaan termasuk LGBT. Meskipun pada dasarnya pemerintahan daerah tidak memiliki acuan dalam perumusan undang-undang mengenai hal ini namun tidak berarti dilarang karena masing-masing daerah memiliki otoritas untuk membuat kebijakan/peraturan selama tidak bertentangan dengan undang-undang nasional yang ada (desentralisasi).

Hingga saat ini, respon mayoritas masyarakat, akademisi, pemerintah, dan kalangan agama menolak perilaku tersebut. Usulan agar dikeluarkannya perundangundangan anti LGBT membuat posisi komunitas LGBT di Indonesia saat ini terancam. Oleh karena itu, hari LGBT yakni 1 Maret hingga saat ini digelar secara tertutup.

Penelitian mengenai LGBT telah banyak dilakukan oleh para pakar dengan displin ilmu yang berbeda, seperti bagaimana LGBT dalam pandangan Islam, LGBT dalam pandangan psikologis, LGBT dalam pandangan kesehatan, LGBT dalam pandangan sosiologis, dan lain sebagainya. Pandangan-pandangan tersebut jelas membuahkan hasil atau interpretasi yang berbeda-beda. Dalam hukum Islam misalnya, jelas dengan tegas dikatakan bahwa perilaku LGBT dilarang dan merupakan perbuatan tercela dan dilaknat oleh Allah Swt. Hal ini sebagaimana yang telah diketahui bersama bahwa Al-Qur'an dengan sangat gamblang menyampaikan bagaimana dan alasan apa negeri kaum Sodom pada masa Nabi Luth a.s. diberi azab oleh Allah Swt. Berikut beberapa ayat Al-Qur'an yang membahas tentang perilaku LGBT: 
"Dan (Kami telah mengutus) Luth (kepada kaumnya). Ingatlah takkala dia berkata kepada mereka: "Mengapa kamu mengerjakan perbuatan faahisyah (homoseksual) itu, yang belum pernah dikerjakan oleh seseorang pun (di dunia ini sebelummu)?”. Sesungguhnya kamu mendatangi lelaki untuk melepaskan nafsumu (kepada mereka), bukan kepada wanita, malah kamu ini adalah kaum yang melampaui batas." (QS. Al-A'raf: 80-81). Point penting yang disampaikan pada ayat ini adalah bahwasanya pertama kali perilaku homoseksual dilakukan oleh umat manusia yakni kaum Sodom pada masa Nabi Luth a.s. Mereka disebut sebagai kaum yang melampaui batas.

"Dan datanglah kepadanya kaumnya dengan bergegas-gegas. Dan sejak dahulu mereka selalu melakukan perbuatan-perbuatan yang keji (lewat, homoseksual). Luth berkata: "Hai kaumku, inilah puteri-puteriku, mereka lebih suci bagimu, maka bertakwalah kepada Allah dan janganlah kamu mencemarkan (nama)ku terhadap tamuku ini. Tidak adakah di antaramu seorang yang berakal?" (QS. Hud: 78). Ayat ini menjelaskan ketika kaum Sodom mendatangi rumah Nabi Luth a.s. karena mengetahui keberadaan tetamu Nabi Luth a.s. (malaikat yang menyamar sebagai pemuda yang cukup tampan).

"Mengapa kamu mendatangi jenis lelaki di antara manusia dan kamu tinggalkan isteri-isteri yang dijadikan oleh Tuhanmu untukmu, bahkan kamu adalah orang-orang yang melampaui batas.” (QS. Asy Syu'araa': 165-166). Ayat ini menunjukkan bahwa perilaku ini juga dialami oleh pasangan yang sudah bersuami istri.

"Maka tatkala datang azab Kami, Kami jadikan negeri kaum Luth itu (terjungkir balik sehingga) yang di atas ke bawah, dan Kami hujani mereka dengan batu dari tanah yang terbakar dengan bertubi-tubi” (QS. Hud, ayat 82). Ayat ini menggambarkan bagaimana kaum Nabi Luth diazab disebabkan perbuatan/perilaku tersebut.

Islam memandang hubungan seksual bukan sekedar cara untuk menuruti dorongan seksual atau jalan memperoleh kepuasan seksual, tetapi lebih dalam 
maknanya dari itu yakni berkaitan dengan kebutuhan manusia untuk berkembang biak $^{3}$, menjaga kesehatan, dst. Dimana hubungan ini diperbolehkan jika sudah melakukan pernikahan. Perilaku homoseksual (LGBT) dipandang menyalahi fitrah manusia itu sendiri, dimana Allah menciptakan manusia berpasang-pasangan yakni perempuan dengan laki-laki. Sebagaimana Allah SWT berfirman dalam Surah ArRum ayat 21 yang artinya:

"Dan di antara tanda-tanda kekuasaan-Nya ialah Dia menciptakan untukmu isteri-isteri dari jenismu sendiri, supaya kamu cenderung dan merasa tenteram kepadanya, dan dijadikan-Nya di antaramu rasa kasih dan sayang. Sesungguhnya pada yang demikian itu benar-benar terdapat tanda-tanda bagi kaum yang berfikir." Oleh karena beragamnya pandangan terhadap perilaku LGBT maka pada tulisan ini akan dijelaskan perbedaan-perbedaan pandangan tersebut. Dengan kata lain, bagaimana LGBT sebagai masalah (objek) dipandang oleh berbagai sudut pandang dan kedudukan pandangan Islam dan pandangan lainnya dalam memandang masalah.

Selanjutnya, pada tulisan ini akan dijelaskan pula bagaimana sebenarnya LGBT lebih tepatnya bukan merupakan krisis karakter, krisis moral, penyakit mental, melainkan krisis akidah akhlak. Oleh karena itu, berbicara mengenai LGBT bukan berarti berbicara tentang karakter atau akhlak saja melainkan lebih mendasar dari itu yakni akidah, terutama akidah Islam. Kesalahan kita dalam mengidentifikasi penyakit selama ini menjadikan kita salah dalam memberikan obat (solusi). Dengan kata lain, pendidikan karakter bukan merupakan solusi mendasar dalam pencegahan LGBT akan tetapi pendidikan akidah akhlak.

\footnotetext{
${ }^{3}$ Ibid., 100.
} 


\section{Kedudukan Pandangan Islam}

Islam dikatakan sebagai satu-satunya agama yang benar di muka bumi sedangkan agama yang lain telah mengalami perubahan dan penyimpangan. Islam dikatakan pula sebagai agama yang sempurna, dimana ia mengatur dan mencakup semua aspek kehidupan. Tidak ada perkara yang luput dari kacamata Islam, baik politik, ekonomi, sosial, ibadah, dan seterusnya telah diatur sedemikian rupa dalam Islam. Acuannya adalah Al-Qur'an, sunnah, dan ijtihad, sehingga selama suatu perkara tidak berseberangan dengan ajaran Islam yang termuat dalam ketiga sumber tersebut maka diperbolehkan atau dianggap sah-sah saja.

Sebenarnya jika kita ingin jujur pada diri kita sendiri, baik sebagai seorang muslim maupun yang bukan beragama Islam, ketika mengetahui ajaran Islam, akal kita membenarkan ajaran-ajaran tersebut. Karena hakikatnya segala hal yang telah diatur dalam Islam tidak pernah menyalahi atau berseberangan dengan fitrah dan akal manusia. Semuanya diatur sedemikian rupa dengan tujuan untuk menciptakan tatanan kehidupan yang baik dan teratur. Hanya saja kemudian sebagaian mengakui kebenarannya dan sebagian lain mengingkari. Islam dalam memandang suatu perkara telah mengantisipasi dan mempertimbangkan segala kemungkinan positif dan negatif dari perkara tersebut. Hal tersebut jelas, karena pembuat hukum Islam atau aturannya adalah Allah yakni tuhannya manusia sendiri, Yang Maha Mengetahui, Maha Teliti, Maha Perkasa dan Maha Bijaksana. Sebagaimana Allah Swt. berfirman dalam Surat Al-Ahzab ayat 36 yang artinya,

"Tidaklah pantas bagi seorang lelaki yang beriman, demikian pula perempuan yang beriman, apabila Allah dan Rasul-Nya telah menetapkan suatu perkara lantas masih ada bagi mereka pilihan yang lain dalam urusan mereka. Barangsiapa yang durhaka kepada Allah dan Rasul-Nya sungguh dia telah tersesat dengan kesesatan yang amat nyata”. Islam mencakup nilai-nilai universal, tetapi nilai-nilai universal dalam semua lapisan masyarakat belum tentu mencakup nilainilai Islam. Oleh karena itu, tidak jarang dalam suatu masyarakat, nilai A dianggap baik tetapi belum tentu baik dan benar dalam pandangan Islam. Sebagai contoh kita 
jadikan masalah LGBT sebagai objek kajian kita. Agar lebih mudah, penulis memberikan gambaran bagaimana kedudukan Islam dan disiplin ilmu (perspektif) lainnya dalam memandang suatu masalah/objek.

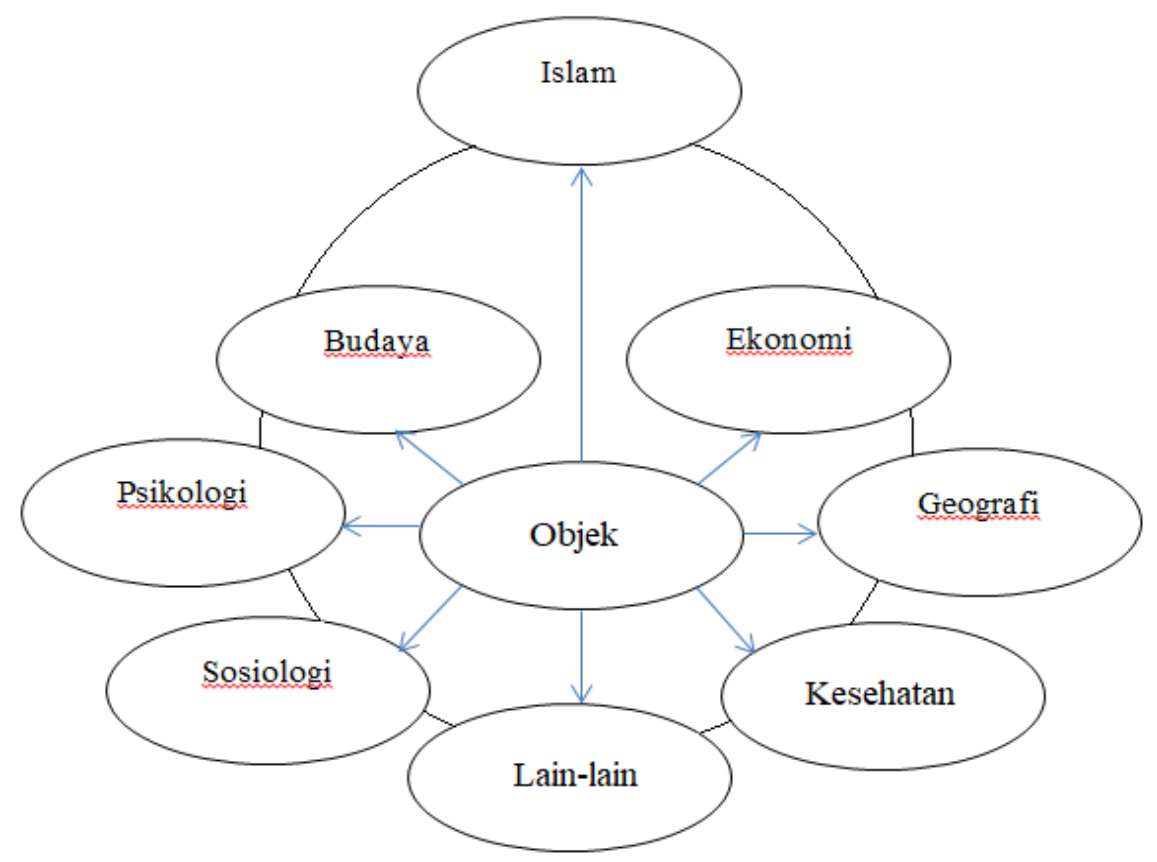

Gambar 1

Dari gambar di atas, kita dapat lihat bagaimana masalah atau "objek" yang berada di tengah, dilihat dari berbagai sudut pandang. Sekarang, mari kita posisikan LGBT sebagai suatu objek, dimana LGBT dilihat dari berbagai sudut pandang yang berbeda-beda.

Dalam sudut pandang psikologis, seksualitas mencakup banyak sekali, bukan hanya dari manusia yang berorientasi heteroseksual (penyuka lawan jenis) melainkan juga yang berorientasi seksual lainnya seperti homoseksual (penyuka sesama jenis, apabila sesama laki-laki disebut dengan istilah gay, dan apabila sesama wanita disebut dengan lesbian), biseksual (penyuka kedua jenis kelamin), dan transgender (LGBT).

American Psycgiatric Assosiation mengakui bahwa homoseksual bukan sebuah bentuk penyakit mental dan menghilangkan klasifikasi yang memasukkan 
homoseksualitas sebagai sebuah penyimpangan, kecuali dalam kasus dimana individu sendiri yang menganggap orientasi seksualnya adalah abnormal. Menurut McWhirter, Reinisch \& Sanders, dan beberapa ahli lainnya, orientasi seksual individu baik heteroseksual maupun homoseksual tampaknya lebih banyak ditemukan oleh kombinasi antara factor genetic, hormonal, kognitif, dan lingkungan. Sebagian besar ahli dalam hal homoseksualitas percaya bahwa tidak ada faktor tunggal yang menyebabkan homoseksualitas dan bobot relative masing-masing faktor berbedabeda dari satu individu dengan individu lainnya. ${ }^{4}$ Berdasarkan pandangan psikologis mengenai homoseksual dan biseksual dapat disimpulkan bahwa perilaku tersebut disebut sebagai kecenderungan orientasi seksual individu yang beragam.

Selanjutnya bagaimana LGBT dalam pandangan kesehatan. Organisasi Kesehatan Dunia (WHO) merilis ICD-11 versi terbaru Klasifikasi Penyakit Internasional, yang menyatakan bahwa transgender tidak lagi dianggap sebagai gangguan mental. Meskipun LGBT dihapus sebagai gangguan mental, namun perilaku ini dj8apat menimbulkan berbagai resiko seperti munculnya penyakit menular seksual. Penyakit menular seksual tersebut seperti gonoreza, sifilis, herpes, klamidia, candida, chancroid, glanuloma inguinale, lymphogranuloma venereum, AIDS, ARC, scabies, PID, trichomonas infection, dan venereal warts. ${ }^{5}$ Dengan demikian, apabila ditilik dari segi kesehatan LGBT dapat memberikan dampak negatif yang berbahaya bahkan beresiko menular dan mengalami kematian.

Kemudian, berikutnya LGBT ditinjau dari sudut pandang sosiologis. Manusia adalah makhluk sosial. Keberlangsungan hidup manusia dari generasi ke generasi merupakan hasil dari perkembangan biak yang dilakukan manusia untuk mempertahankan spesiesnya. Namun, jika LGBT dibolehkan, bagaimana manusia sebagai makhluk sosial ke depannya, tidak hanya berdampak buruk pada

4 Jhon W. Santrock, Life-Span Development: Perkembangan Masa Hidup, terj. Achmad Chusairi, (Jakarta: Erlangga, 2002), Edisi Kelima, jilid II, 85.

5 Masmuri dan Syamsul Kurniawan. "Penyimpangan Seksual: Sebuah Interpretasi Teologi, Psikologi dan Pendidikan Islam”, dalam Jurnal Raheema: Jurnal Studi Gender dan Anak, Vol. 3 No. 1, 2016, 103-104. 
kuantitasnya, tetapi juga berdampak pada bagaimana mental, kesehatan, dan tatanan hidup manusia ke depannya.

Hal ini harus dilihat dari berbagai sudut pandang. Tidak hanya ditilik dari ego/nafsu manusia itu sendiri. Islam dalam hal ini mempertimbangkan segala konsekuensi yang akan terjadi akibat perilaku tersebut. Dengan demikian, merupakan sebuah kewajaran dan bahkan keharusan dan kebenaran jika Islam melarang perilaku tersebut bagi manusia sebagai makhluk yang mulia dan mengemban amanah sebagai khalifah atau pemimpin di muka bumi. Bagaimana mungkin bumi ini akan damai dan tertata dengan baik jika dipimpin oleh manusia-manusia yang bermental lemah, berakhlak buruk, dan tidak sehat. Yang ada adalah kerusakan akan terjadi dimanamana.

Begitu pun seterusnya LGBT dalam pandangan lainnya. Oleh karena itu, pada gambar di atas mengapa penulis meletakkan posisi Islam berada paling atas, berbeda dengan posisi pandangan-pandangan atau disiplin-disiplin ilmu lainnya. Hal ini dikarenakan satu disiplin ilmu boleh saja menilai masalah dari sudut pandang keilmuannya, tetapi Islam menilai suatu masalah dengan mempertimbangkan dari berbagai sudut pandang yang kemudian menjadi suatu hukum yang mantap. Hal ini dapat dilihat dari garis tipis yang berbentuk lingkaran seumpama merangkul semua aspek-aspek di atas. Ilmu Allah itu luas, dan apa yang ditemukan oleh manusia hingga saat ini hanyalah sedikit saja. Akal manusia itu terbatas, karenanya kekurangan dan kelemahan adalah padanya. Pada dasarnya, Islam tidak hanya menilai suatu objek secara doktrinir saja, melainkan segala aturan yang termuat dalam Al-Qur'an yang diwahyukan kepada Nabi Muhammad saw. adalah berdasarkan ilmu-ilmu-Nya yang universal dan mencakup segala sesuatu. Oleh karena itu, Islam menempati posisi paling tinggi, dimana mentaatinya dan memprioritaskan pandangannya adalah wajib terutama yang beriman kepada-Nya. Al-Shatibi dalam konsep maqasidnya menyatakan bahwa, "Tujuan diturunkan syariah oleh Allah Swt. untuk kemaslahatan manusia di dunia dan akhirat. Bukanlah tujuan syari'ah untuk membebankan dan menyusahkan manusia. Hukum syari'ah tetap 
berlaku sebagai beban yang harus direalisasikan. Karena tidak mungkin syari'ah diturunkan bukan untuk dipahami dan dipraktikkan manusia."6

\section{LGBT sebagai Masalah Akidah}

Selama ini LGBT yang marak diperbincangkan dianggap sebagai krisis moral atau krisis karakter. Hal ini tidak berarti salah, akan tetapi lebih tepat dan mendasar perilaku ini merupakan krisis akidah yang kemudian berdampak pada akhlak/karakter. Mengapa demikian? Karena kenyatannya krisis karakter yang selama ini melanda Indonesia, lalu muncullah solusi dengan istilah pendidikan karakter tidak mampu merangkul semua tujuan yang dimaksud. Artinya, pemahaman tentang pendidikan karakter oleh setiap orang tidak selalu sama. Pendidikan karakter yang selama ini diluncurkan adalah pendidikan karakter yang bersifat universal. Dengan kata lain, nilai-nilai yang diajarkan adalah nilai-nilai yang secara umum diakui benar oleh semua lapisan masyarakat/kalangan.

Adapun LGBT yang dipandang sebagai perilaku yang tidak baik dan melampaui batas, setiap individu berbeda pendapat. Mayoritas individu di Indonesia mungkin akan sepakat dengan pernyataan tersebut, tetapi belum tentu dengan individu lainnya, termasuk individu-individu di beberapa negara yang telah disebutkan di atas dimana LGBT dan pernikahan sejenis dilegalkan dan dianggap hal yang wajar. Oleh karena itu penulis membagi nilai menjadi 2, yaitu nilai-nilai universal dan nilai-nilai khusus. Nilai-nilai universal maksudnya adalah nilai-nilai yang diterima oleh manusia secara umum. Adapun nilai-nilai khusus adalah nilai-nilai Islam, dimana nilai-nilai ini pada dasarnya diperuntukkan untuk semua manusia (nilai universal) akan tetapi tidak semua manusia menerima nilai-nilai tersebut. Jika dikotak-kotakkan maka dapat ditarik bahwa Islam mencakup kedua nilai di atas yakni nilai-nilai universal dan nilai-nilai khusus. Menanamkan kedua nilai ini pada tatanan

\footnotetext{
${ }^{6}$ Ahmad Al-Raisuni, Nazariyyat al-Maqasid 'inda al-Imam Al-Shatibi, (Beirut: al-Ma'had al'Alami li al-Fikr al-Islami, 1992), 15.
} 
kehidupan manusia secara keseluruhan adalah tugas atau amanah dari Allah kepada manusia sebagai khalifah di muka bumi.

Berdasarkan kedua pembagian nilai di atas, maka LGBT terletak pada nilainilai khusus. Dimana dalam Islam perilaku tersebut dipandang tidak baik dan benar. Akan tetapi, oleh sebagaian manusia menganggap hal tersebut adalah wajar atau sahsah saja.

Dikarenakan selama ini kita salah dalam melakukan identifikasi dengan menganggap bahwa LGBT sebagai krisis moral/karakter saja maka sewajarnya pula kita salah dalam memberikan obat (solusi/penanganan). Dalam Islam, manusia dipandang sebagai makhluk yang mulia dibandingkan makhluk-makhluk Allah lainnya. Artinya, manusia memiliki kedudukan yang tinggi. Namun, di samping itu disebutkan bahwa "al-insan makan al-khata' wa an-nisyan" yang berarti, "manusia adalah tempatnya salah dan lupa".

Hakikatnya manusia terdiri dari dua unsur yaitu jiwa dan raga. ${ }^{7}$ Jiwa bersifat immaterial sedangkan raga bersifat material. Adapun Ibnu Miskawaih memandang manusia sebagai makhluk yang memiliki macam-macam daya. Menurutnya, macammacam daya dalam manusia tersebut adalah: a. Daya bernafsu (al nafs albahimiyyah), sebagai daya terendah, b. Daya berani (al nafs al-sabu'iyyah), sebagai daya pertengahan, dan c. Daya berpikir (al nafs al-nathiqah), sebagai daya tertinggi. ${ }^{8}$ Kedua unsur manusia baik raga maupun jiwa beserta macam-macam daya yang dimilikinya, menjadikan manusia sebagai makhluk yang kompleks. Dalam mekanisme kerjanya, ketiga jiwa tersebut beserta daya yang dimilikinya berusaha saling berebut untuk merealisasikan kecenderungan dan keinginannya masingmasing. Siapa yang paling berpengaruh, ia akan menguasai dan mempengaruhi perilaku manusia. ${ }^{9}$ Artinya, manusia tidak seperti malaikat yang tidak perlu

\footnotetext{
${ }^{7}$ Ibn Miskawaih, Menuju Kesempurnaan Akhlak: Buku Daras Pertama tentang Filsafat Etika., (Bandung: Mizan, 1994), 35-38.

${ }^{8}$ Suwito dan Fauzan, Sejaran Pemikiran para Tokoh Pendidikan, (Bandung: Angkasa, 2003), 88.

${ }^{9}$ Ibid., 89.
} 
mengontrol nafsu dalam melakukan kebaikan. Oleh karena itu, dalam hal ini penulis membagi manusia kedalam 4 tipe, yakni:

a. Manusia yang berakidah dan berakhlak

b. Manusia yang berakidah tetapi tidak berakhlak

c. Manusia yang tidak berakidah tetapi berakhlak

d. Manusia yang tidak berakidah dan tidak pula berakhlak.

Maksud dari tipe pertama yakni manusia yang berakidah dan berakhlak adalah manusia yang memiliki keyakinan (percaya kepada rukun iman dalam Islam). Tipe ini adalah idealnya seorang muslim atau dapat disebut sebagai muslim sejati. Meskipun demikian, tidak berarti tipe pertama tidak pernah melakukan kesalahan. Kedua, manusia yang berakidah tetapi tidak berakhlak adalah manusia yang percaya rukun iman Islam tetapi tidak memiliki akhlak yang baik. Biasanya, manusia dengan tipe ini adalah mereka yang memiliki iman tetapi tidak cukup kuat, meyakini tetapi belum terealisasikan cerminan imannya dalam bentuk tindakan/perbuatan/akhlak yang mulia. Tipe ini dalam mengamalkan syari'ah Islam masih cenderung memilihmilih. Ketiga, manusia yang tidak berakidah tetapi berakhlak adalah manusia yang tidak mengimani rukun iman dalam Islam, tetapi memiliki akhlak yang baik. Manusia tipe ini biasanya memiliki keyakinan (agama) selain Islam atau mereka yang memiliki kecenderungan berbuat baik. Dan yang keempat, manusia yang tidak berakidah dan tidak berakhlak adalah manusia yang tidak beriman juga tidak berakhlak mulia. Dari keempat tipe di atas, LGBT berpotensi menyebar atau dilakukan pada manusia tipe dua, tiga, dan empat. Tetapi masing-masing tipe berbeda porsi. Tipe dua, hanya sebagian kecil, tipe tiga lebih banyak daripada tipe dua, dan tipe empat paling banyak.

Jika dikaitkan antara keempat tipe di atas dengan penggolongan orang yang tidak menegakkan atau tidak mau mematuhi hukum Allah adalah sebagaimana firman Allah di bawah ini:

a. "Barangsiapa yang tidak berhukum dengan apa yang Allah turunkan maka mereka itulah para pelaku kekafiran.” (QS. Al-Ma'idah: 44). 
b. "Barangsiapa yang tidak berhukum dengan apa yang Allah turunkan maka mereka itulah para pelaku kezaliman.” (QS. Al-Ma'idah: 45).

c. "Barangsiapa yang tidak berhukum dengan apa yang Allah turunkan maka mereka itulah para pelaku kefasikan.” (QS. Al-Ma'idah: 47)

Berdasarkan pada ketiga ayat di atas, Imam Ibnul Jauzi mengatakan bahwa barangsiapa yang tidak berhukum dengan apa yang diturunkan Allah karena menentang hukum itu dalam keadaan dia mengetahui bahwa Allah telah menurunkannya sebagaimana halnya keadaan kaum Yahudi, maka dia adalah kafir. Adapun barangsiapa yang tidak berhukum dengannya karena kecondongan hawa nafsunya tanpa ada sikap penentangan terhadap hukum Allah, maka dia adalah orang yang zalim lagi fasik. ${ }^{10}$ Selanjutnya Ibnu Mas'ud dan al-Hasan menafsirkan, "Ayat itu berlaku umum bagi siapapun yang tidak berhukum dengan hukum yang diturunkan Allah, baik dari kalangan umat Islam, Yahudi, dan orang-orang kafir. Artinya, apabila dia meyakini dan menghalalkan perbuatannya itu. Adapun orang yang melakukannya sementara dia berkeyakinan dirinya melakukan perbuatan yang haram, maka dia tergolong orang muslim yang berbuat fasik...."11

Di Indonesia sendiri, dapat kita saksikan bahwa sebagian dari pelaku LGBT adalah mereka yang beragama Islam. Oleh karena itu dapat digolongkan mereka ke dalam tipe 2 dengan kadar keimanan yang tipis Adapun sebagian lainnya adalah tipe 3 dan 4, tipe manusia ini dapat kita temukan di beberapa negara seperti Amerika, Thailand, dan lain sebagainya.

LGBT adalah persoalan akidah. Hal ini sejalan dengan ruang lingkup mata pelajaran Akidah Akhlak di sekolah/madrasah pada lampiran PMA No 165 Tahun 2014 tentang pedoman kurikulum di madrasah. Oleh karena itu, tanpa penanaman akidah yang kuat terhadap generasi bangsa Indonesia termasuk oleh agama lainnya, kemungkinan besar pada tahun-tahun berikutnya jumlah LGBT akan terus mengalami

\footnotetext{
${ }^{10}$ Ibnu Al-Jauzi, Zad al-Masir fi Ilm al-Tafsir, (Damaskus: Maktab al-Islamiy, 1984), 386.

${ }^{11}$ Abū Abdillah Muhammad al-Qurtḥubi, Al-Jamı̄’ li Aḥkām Alquran, (Beirut: Muassasah alRisālah, 2006), jilid 7, 497.
} 
peningkatan. Lebih jauh, bahkan akan mendapat pengakuan atau dilegalkan sebagaimana negara-negara lainnya.

\section{Pendidikan Akidah Akhlak sebagai Pencegahan LGBT}

Sebagaimana penjelasan di atas bahwa LGBT merupakan persoalan akidah akhlak. Hal ini sejalan dengan ruang lingkup mata pelajaran Akidah-Akhlak di Madrasah Aliyah yang meliputi: a. Aspek akidah, b. Aspek akhlak terpuji, c. Aspek akhlak tercela, d. Aspek adab, dan e. Aspek kisah.

Aspek akidah terdiri atas: prinsip-prinsip akidah dan metode peningkatannya, al-Asma' al-Husna, konsep tauhid dalam Islam, syirik dan implikasinya dalam kehidupan, pengertian dan fungsi ilmu kalam serta hubungannya dengan ilmu-ilmu lainnya, dan aliran-aliran dalam ilmu kalam (klasik dan modern). Aspek akhlak terpuji meliputi: masalah akhlak meliputi pengertian akhlak, induk-induk akhlak terpuji dan tercela, metode peningkatan kualitas akhlak; macam-macam akhlak terpuji seperti husnuz-zan, taubat, akhlak dalam berpakaian, berhias, perjalanan, bertamu dan menerima tamu, adil, rida, amal salih, persatuan dan kerukunan, akhlak terpuji dalam pergaulan remaja; serta pengenalan tentang tasawuf. Aspek akhlak tercela meliputi: riya, aniaya, dan diskriminasi, perbuatan dosa besar (seperti mabukmabukan, berjudi, zina, mencuri, mengonsumsi narkoba), israf, tabzir, dan fitnah. Aspek adab meliputi: adab kepada orang tua dan guru, adab membesuk orang sakit, adab berpakaian, berhias, perjalanan, bertamu, dan menerima tamu, melakukan takziyah, adab bergaul dengan orang yang sebaya, yang lebih tua yang lebih muda dan lawan jenis, adab membaca Al-Qur'an dan berdoa. Aspek Kisah meliputi: Kisah kelicikan saudara-saudara Nabi Yusuf a.s., Ulul Azmi, Kisah Sahabat dan Tokoh Fatimatuzzahrah, Abdurrahman bin Auf, Abu Dzar al-Ghifari, Uwais al-Qarni, Imam al-Ghazali, Ibn Sina, Ibn Rusyd, dan Muhammad Iqbal. ${ }^{12}$

\footnotetext{
${ }^{12}$ Lampiran Keputusan Menteri Agama Republik Indonesia Nomor 165 Tahun 2014 tentang Kurikulum 2013 Mata Pelajaran Pendidikan Agama Islam dan Bahasa Arab Pada Madrasah, 53.
} 
Di atas dipaparkan bahwa pada aspek akhlak tercela termasuk di dalamnya adalah "aniya, diskriminasi, perbuatan dosa besar (zina)". Secara sepintas, LGBT (pro LGBT) akan mengatakan bahwa diskriminasi dan aniaya adalah perbuatan tercela. Oleh karena itu, masyarakat Indonesia yang menganiaya, dan mendiskriminasi kelompok mereka memiliki akhlak yang tercela. Akan tetapi, mereka tidak menyadari bahwa perbuatan dosa berupa zina (termasuk LGBT) juga merupakan akhlak tercela. Jika kita tinjau dari segi akidah yakni konsep tauhid, dimana tidak ada persekutuan terhadap Allah dan mengimani rukun iman maka tampak bahwa pengakuan, pembenaran, pembolehan terhadap perilaku LGBT berarti mengingkari iman kepada Nabi dan kitab Allah, dan rukun-rukun iman lainnya. Mengapa? Karena Al-Qur'an telah menjelaskan bahwa LGBT adalah haram dan merupakan perbuatan yang dilaknat Allah. Hal ini sebagaimana fatwa yang dikeluarkan oleh Majelis Ulama Indonesia mengenai LGBT pada 31 Desember 2014. Dengan demikian, individu LGBT secara tidak langsung telah mengingkari kalam Allah. Adapun perlakuan diskriminatif terhadap mereka bukan berarti mencela mereka tanpa sebab, tetapi karena perilaku tersebut tidak boleh mendapatkan dukungan karena dapat merusak manusia dan tatanan kehidupan.

Akidah merupakan suatu hal yang tidak akan mengalami perubahan baik dalam masa/waktu dan tempat. Akidah Islam akan selamanya seperti itu, tidak bertambah dan tidak pula berkurang. Dengan demikian, hingga akhir kehidupan, LGBT tidak akan pernah dianggap benar oleh Islam.

Akhlak seorang muslim merupakan cerminan dari akidah yang dimilikinya. Sikapnya yang kontra terhadap LGBT adalah manifestasi dari iman terhadap kitabNya, dan iman terhadap kelima rukun iman Islam lainnya. Begitupun sebaliknya, seseorang yang mendukung adanya gerakan LGBT merupakan manifestasi seberapa besar keyakinannya terhadap keenam rukun iman dalam Islam. Beriman kepada Allah, malaikat, kitab-kitab-Nya, hari akhir, dan qadha dan qadar berarti menyakini sepenuhnya bukan sebagiannya. Dengan kata lain, seseorang yang mengaku beriman kepada kitab Allah misalnya, berarti menerima dan meyakini semua ayat-ayat yang 
terkandung didalamnya, bukan mengimani atau menerima sebagian ayat dan mengingkari atau tidak menerima sebagian lainnya.

Dari uraian di atas, bagaimana seharusnya pendidikan akidah akhlak guna antsipasi atau pencegahan perilaku LGBT? Menjawab pertanyaan ini, maka sedikit akan kita kaitkan dengan akhlak dan pendidikan menurut Ibnu Miskawaih. Menurut Ibnu Miskawaih, "akhlak adalah suatu sikap mental yang mendorongya untuk berbuat, tanpa pikir dan pertimbangan". Keadaan atau sikap jiwa ini terbagi kepada dua yakni ada yang berasal dari watak (tempramen) dan ada yang berasal dari kebiasaan atau latihan. Dengan kata lain, tingkah laku manusia mengandung dua unsur yaitu: 1) unsur watak naluri, dan 2) unsur kebiasaan atau latihan. ${ }^{13}$ Baginya, individu yang memiliki watak naluri yang buruk dapat diatasi dengan melakukan pembiasaan dan latihan. Dengan demikian, pembentukan karakter yang baik dapat dilakukan melalui pendidikan dimana penekanannya di sini adalah penanaman akidah dan pembentukan karakter (karakter sebagai manifestasi akidah). Watak yang buruk dapat dilatih melalui pendidikan. Kemudian baik guru, keluarga, maupun lingkungan harus memberikan teladan yang baik untuk dapat ditiru oleh siswa.

Selain itu, pendidikan akidah akhlak di Indonesia harus bersifat kontekstual. Artinya, tidak hanya sebatas menyampaikan enam rukun iman kepada siswa, lalu dihafalkan, kemudian ketika ujian siswa diminta untuk menyebutkan keenam rukun tersebut. Jika selama ini implementasi pendidikan akidah akhlak sebagaimana demikian, maka hal wajar jika saat ini banyak kalangan muda yang terjerumus dalam perilaku tersebut. Pendidikan akidah akhlak harus up to date dengan perkembangan zaman sehingga dalam pembelajaran akidah akhlak siswa dapat merasakan manfaat, kegunaan, serta tujuan dan maksud dari pada pembelajaran tersebut. Pendidikan akidah akhlak bersifat kontekstual menciptakan pembelajaran yang hidup dan bermakna.

${ }^{13}$ Ahmad Daudy, Kuliah Filsafat Islam, (Bandung: PT. Bulan Bintang, 1992), 61. 
Metode pendidikan atau pembelajaran Akidah Akhlak harus pula menekankan pada sikap kritis siswa terhadap fenomena atau permasalahan yang ada. Dengan menumbuhkan sikap kritis siswa melalui bimbingan dan arahan oleh guru, keyakinannya akan semakin kuat terhadap kebenaran yang sedang ia pegang.

Disiplin ilmu lainnya juga perlu dikaitkan dengan pendidikan Akidah Akhlak, seperti ilmu biologi, ilmu fisika, ilmu astronomi, ilmu psikologi, sosial, dan lain sebagainya. Dengan demikian akidah siswa akan semakin kuat. Pendidikan Akidah Akhlak harus mampu mengembangkan cara berpikir tingkat tinggi siswa (high order thingking skill/ HOTS) yang berbasis problem solving. Karena itu, guru sebagai fasilitator dalam proses pembelejaran harus mampu menumbuhkan dan mengembangkan perasaan ingin tahu pada diri siswa. Misalnya, dalam mempelajari iman kepada qadha dan qadar. Siswa diminta untuk mencari informasi mengenai apa yang dimaksud dengan iman kepada qadha dan qadar dan bagaimana penerapannya dalam kehidupan sehari-hari. Mempelajari rukun iman keenam ini tidak cukup menjelaskan pengertian dan beberapa aliran yang menafsirkannya. Cara demikian hanya akan memberikan segudang tumpukan pengetahuan kepada siswa. Berbasis problem solving berarti bagaimana siswa setelah mempelajari suatu materi misalnya, dapat ia terapkan atau dapat memberikannya kemudahan dalam memecahkan masalah kehidupannya. Mempelajari iman kepada qadha dan qadar, mampu menjadikannya optimis dalam hidup, bertawakkal, berusaha keras atau berikhtiar untuk mencari ketetapan atau takdir-Nya. Apabila dikaitkan dengan perilaku LGBT, maka dengan iman kepada qadha dan qadar mengingatkannya agar bersyukur dan menerima takdirnya baik sebagai perempuan atau laki-laki.

Evaluasi pendidikan Akidah Akhlak harus menekannya pada 2 (dua) penilaian yaitu aspek spiritual dan aspek sikap. Dengan demikian, siswa menyadari bahwa hal yang harus mereka capai dalam pembelajaran tidak hanya setumpukan pengetahuan melainkan bagaimana ia menerapkan nilai-nilai Islam dalam diri mereka. Fokus penilaian Akidah Akhlak adalah bagaimana hubungan siswa dengan Tuhan-Nya dan 
bagaimana siswa dengan orang-orang di sekitarnya (seluruh makhluk yang hidup maupun yang mati).

Terakhir, pendidikan Akidah Akhlak sebagai salah satu komponen dalam Pendidikan Agama Islam di perguruan tinggi harus pula mendapatkan perhatian sebagaimana pendidikan Akidah Akhlak di madrasah maupun mata pelajaran PAI di sekolah. Hal ini dikarenakan tahap perkembangan mahasiswa secara psikologis berada pada masa dewasa awal. Masa dewasa awal dimulai pada umur 18 tahun sampai kira-kira 40 tahun. ${ }^{14}$ Aktivitas seksual meningkat di usia 20-an tahun baik ketika orang hidup bersama sebagai pasangan suami istri atau pasangan kumpul kebo. ${ }^{15}$ Masa dewasa awal adalah masa peralihan dari masa remaja menuju masa dewasa, masa untuk bekerja dan bercinta. Masa dewasa awal juga merupakan masa peralihan dari ketergantungan ke masa mandiri baik dari ekonomi, kebebasan menentukan diri, dan pandangan masa depan lebih realistis. Di Amerika, kebanyakan homoseksual (lesbian, gay, dan transgender) mulai menyadari dirinya mempunyai kecenderungan berbeda ketika dalam usia muda. Studi menunjukan perilaku homoseksual dan ketertarikan sesama jenis banyak dijumpai sejak usia 15, prevalensinya pada pria di Amerika 20.8\%, UK 16.3\%, dan Amerika $18.5 \%$. Sedangkan pada kelompok wanita masing-masing 17.8\%, 18.6\%, and $18.5 \%$. Keadaan ini memperlihatkan kelompok usia sekolah adalah usia yang rentan untuk mulai terlibat dalam hubungan sesama jenis. Keputusan untuk menjadi homoseksual kebanyakan terjadi pada usia dewasa muda atau pada usia ketika mereka kebanyakan menjadi mahasiswa. ${ }^{16}$ Oleh karena itu, Pendidikan Agama Islam yang memuat pendidikan Akidah Akhlak tidak boleh dikesampingkan baik di PTU maupun PTKI. Penekanan terhadap akidah dan pembentukan karakter harus konsisten dilakukan baik

\footnotetext{
${ }^{14}$ Laura E. Berk, Development Through The Lifespan: Dari Dewasa Awal sampai Menjelang Ajal, terj. Daryatno, (Yogyakarta: Pustaka Pelajar, 2012), Edisi Kelima, 4.

${ }^{15}$ Laura E. Berk, Development Through The Lifespan: Dari Dewasa Awal sampai Menjelang Ajal, terj. Daryatno, (Yogyakarta: Pustaka Pelajar, 2012), Edisi Kelima, 23.

${ }^{16}$ Pusat Penelitian Kesehatan Universitas Indonesia, "Laporan Kajian Pandangan Masyarakat terhadap Lesbian, Gay, Biseksual, dan Transgender (LGBT) di Jakarta, Bogor, Depok, dan Tangerang", 2015, 1.
} 
di sekolah maupun di PT. Bukan merupakan rahasia umum jika kebanyakan pelaku LGBT adalah kalangan mahasiswa. Dengan demikian, PT tidak boleh mengesampingkan hal tersebut apalagi sampai menjadikan mata kuliah Pendidikan Agama Islam sebagai mata kuliah sampingan/formalitas belaka. Penanaman akidah yang mantap pada mahasiswa dapat dilakukan dengan pembendaharaan ilmu keagamaan Islam yang lebih luas dan mendalam, dengan menitikberaatkan pada keaktifan mahasiswa untuk berpikir tingkat tinggi.

\section{Kesimpulan}

Di tengah semakin maraknya LGBT, hal ini tidak boleh disepelekan atau dikesempangkan oleh masyarakat Indonesia yang mayoritas memeluk agama Islam dan agama samawi lainnya seperti Nasrani. Persoalan LGBT tidak hanya persoalan karakter, moral, atau nilai-nilai di suatu bangsa, akan tetapi juga merupakan persoalan akidah akhlak. Apabila LGBT hanya dianggap sebatas persoalan karakter atau nilainilai saja, maka tidak menutup kemungkinan suatu saat perilaku tersebut akan diterima oleh masyarakat. Hal ini dapat terjadi karena dipengaruhi oleh pemikiranpemikiran yang tidak sejalan dengan ajaran Islam dan juga kecenderungan individu dalam mengikuti hal yang lumrah (nafsu) dilakukan oleh banyak orang. Pergeseran terhadap nilai-nilai dari masa ke masa akan memiliki kemungkinan besar atas pembolehan dan pelegalan terhadap perilaku tersebut.

Islam sebagai agama yang syumul atau menyeluruh memiliki posisi atau kedudukan berada paling atas dibandingkan kedudukan pandangan-pandangan lainnya. Selain itu, pendidikan Akidah Akhlak sebagai solusi pencegahan LGBT dapat dilakukan dengan: 1) melakukan pembiasaan dan latihan melalui penanaman akidah yang kuat sehingga tebentuk karakter yang mulia, 2) pemberian teladan yang baik oleh lingkungan sekitarnya baik keluarga, guru, dan masyarakat sekitar, 3) pendidikan Akidah Akhlak harus bersifat kontekstual, 4) metode pembelajaran Akidah Akhlak harus pula menekankan pada sikap kritis siswa terhadap fenomena 
atau permasalahan yang ada, 5) pengaitan pendidikan Akidah Akhlak dengan disiplin ilmu lainnya, 6) pendidikan Akidah Akhlak berbasis problem solving, 7) evaluasi pembelajaran Akidah Akhlak menekankan pada aspek spiritual dan aspek sikap, dan 8) perhatian lebih oleh perguruan tinggi terhadap mata kuliah Pendidikan Agama Islam karena perguruan tinggi adalah wadah berkumpulnya mahasiswa sebagai seorang individu yang dewasa. Perguruan Tinggi harus berupaya menumbuhkembangkan mahasiswa yang berakidah dan berakhlak mulia (berkarakter) di samping keahlian dalam keilmuannya.

\section{Daftar Referensi}

Al-Jauzi, Ibnu, Zad al-Masir fi Ilm al-Tafsir, Damaskus: Maktab al-Islamiy, 1984.

Al-Raisuni, Ahmad, Nazariyyat al-Maqasid 'inda al-Imam Al-Shatibi, Beirut: alMa'had al-'Alami li al-Fikr al-Islami, 1992.

Al-Qurthubi, Abū Abdillah Muhammad, Al-Jamı̄’ li Aḥkām Alquran, Jilid 7, Beirut: Muassasah al-Risālah, 2006.

Berk, Laura E., Development Through The Lifespan: Dari Dewasa Awal sampai Menjelang Ajal, Edisi Kelima, terj. Daryatno, Yogyakarta: Pustaka Pelajar, 2012

Daudy, Ahmad, Kuliah Filsafat Islam, Bandung: PT. Bulan Bintang, 1992.

Lampiran Keputusan Menteri Agama Republik Indonesia Nomor 165 Tahun 2014 tentang Kurikulum 2013 Mata Pelajaran Pendidikan Agama Islam dan Bahasa Arab Pada Madrasah.

Masmuri dan Syamsul Kurniawan. "Penyimpangan Seksual: Sebuah Interpretasi Teologi, Psikologi dan Pendidikan Islam", dalam Jurnal Raheema: Jurnal Studi Gender dan Anak, Vol. 3 No. 1, 2016.

Miskawaih, Ibn, Menuju Kesempurnaan Akhlak: Buku Daras Pertama tentang Filsafat Etika., Bandung: Mizan, 1994.

Oetomo, Dede dan Khanis Suvianita, "Hidup sebagai LGBT di Asia: Laporan Nasional Indonesia (Tinjauan dan Analisa Partisipatif tentang Lingkungan 
Hukum dan Sosial bagi Orang dan Masyarakat Madani Lesbian, Gay, Biseksual, dan Transgender (LGBT), 2013.

Pusat Penelitian Kesehatan Universitas Indonesia, "Laporan Kajian Pandangan Masyarakat terhadap Lesbian, Gay, Biseksual, dan Transgender (LGBT) di Jakarta, Bogor, Depok, dan Tangerang”, 2015.

Santrock, Jhon W., Life-Span Development: Perkembangan Masa Hidup, Edisi Kelima, Jilid II, terj. Achmad Chusairi, Jakarta: Erlangga, 2002.

Suwito dan Fauzan, Sejaran Pemikiran para Tokoh Pendidikan, Bandung: Angkasa, 2003. 